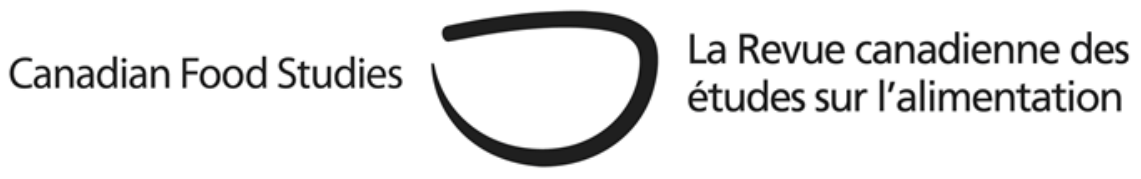

Original Research Article

\title{
Growing with Lady Flower Gardens: Governance in a land-based initiative focused on building community, well-being and social equity through food
}

Ashley M. Roszko* and Mary A. Beckie

University of Alberta

Abstract

The local food sector has been gaining strong momentum in the province of Alberta but inclusiveness, social equity, and affordability remain issues of concern. Lady Flower Gardens (LFG) is a community-based initiative that is working to address these issues. Established in 2012 on private land in the northeast edge of Edmonton, Alberta, LFG provides opportunities for marginalized and disadvantaged individuals to develop skills in growing food for their own consumption, contribute a share of the harvest to the Edmonton Food Bank, as well as develop relationships and build community in a healthy and safe environment. LFG collaborates with a number of social service agencies and two universities in the development of this land-based, experiential learning model. In this case study we examine LFG's evolving governance structure, from a small informal grassroots initiative to a self-governed Part 9 non-profit company, registered with the provincial government. We gathered data from in-depth semi-structured interviews, site visits and documentary research. Our analysis uses a food justice lens and the Policy Arrangement Approach as adapted by Van der Jagt et al. (2017) to examine LFG's actors, partnerships and participation, resources, discourse, and rules. Investigating these dimensions of LFG provides insights into the complexity of factors, both internal and external, that have influenced the development and governance of this local food initiative and its ability to contribute to inclusiveness, social equity, and food justice. 
Our research reveals that LFG aligns strongly with FLEdGE's good food principles of food access and ecological resilience, while also intersecting with the principle of farmer livelihoods through the creation of new training opportunities.

Keywords: Local food initiative; urban agriculture; food justice; governance; Policy Arrangement Approach

\section{Introduction}

Edmonton, Alberta's provincial capital, is one of Canada's fastest growing cities (pop. 972,223) and the northernmost metropolis (pop. 1,461,182) in North America (City of Edmonton, 2019). Growth has been linked to high employment and income opportunities that, until recently, have been primarily driven by the province's oil and gas industry. Yet, despite decades of prosperity and what has been coined the "Alberta Advantage" (Precht, 2019), Alberta has "the largest gap between the rich and the poor of all provinces, with the richest $1 \%$ earning 46 times the poorest $10 \%$ of the provincial population" (Abt \& Ngo, 2018, p. 2). The current historic low in the price of oil has further exacerbated this situation; Edmonton has the highest unemployment rate (8.1\%) of any major city in Canada (Statistics Canada, 2020). As employment and income has gone down, food insecurity and demand for food assistance has spiked.

Edmonton was the first city in Canada to establish a food bank as a temporary relief program during the recession of the 1980s (Tarasuk, 2001). Nearly forty years later, demand for food assistance has not gone away. From 2015 to 2018 there was a 50\% increase in demand (Edmonton Food Bank, 2018). The Food Bank also works with over 250 service agencies in the city to deliver approximately 500,000 meals and snacks monthly (Edmonton Food Bank, 2018). Those experiencing food insecurity are members of vulnerable or marginalized groups, such as low income and unemployed individuals, as well as people experiencing homelessness.

Edmonton and other Canadian cities' increasing reliance on the emergency food sector run by non-profit organizations and volunteers is, in part, linked to government cuts to social assistance programs (Abt \& Ngo, 2018). But it is also tied to inequalities and disparities associated with the dominant, globalized food system, a system where transnational corporations, productivity, and profits rule (Clapp, 2014).

In response to these and other problems associated with the conventional agri-food system, a local food movement has arisen that is being driven by a different set of values including re-embedding food in place, rebuilding local capacity, improving food quality and nutrition, and developing more socially just and ecologically sustainable food systems (Albrecht $\&$ Smithers, 2018). A wide array of local food initiatives (LFIs) have emerged, such as farmers markets, community supported agriculture, collective kitchens and community gardens. However, there are questions as to how far the local food movement has come in creating a more sustainable, inclusive, and socially just food system (Allen, 2010). 
Finding ways to increase local food access, as well as inclusivity and democratic decision making in the governance of local food systems are topics of increasing interest to both scholars and practitioners.

Lady Flower Gardens (LFG), a community-based initiative located on the northeast edge of Edmonton, is working to address these issues. Established in 2012 on private land (15 acres cultivated, 75 acres old growth forest) by a retired market gardener and his partner (LFG codirectors), LFG provides opportunities for disadvantaged individuals to develop skills in growing food for their own consumption, contribute a share of the harvest to the Edmonton Food Bank, develop relationships, and build community in a healthy and safe environment (Lady Flower Gardens, n.d.). LFG partners with several Edmonton-based social service agencies who bring their community members to the garden, as well as academics and students from two universities in the ongoing development of this land-based, experiential learning model. The highly productive land, its location along the North Saskatchewan River, and market gardening expertise and resources of the landowners are critical assets for the success of the garden. Each year, LFG gardeners harvest approximately 50,000 lbs of vegetables for the Edmonton Food Bank and 20,000 lbs for themselves and their agencies.

As researchers affiliated with the Food Locally Embedded, Globally Engaged (FLEdGE) community-engaged research partnership, our interest in LFG focused initially on the contribution of this unique private land-based model to food justice. To further our analysis, we integrated a food justice lens with the Policy Arrangement Approach (PAA) adapted by Van der Jagt et al. (2017) to examine LFG's evolving governance structure, from a small informal grassroots initiative to a self-governed, Alberta registered Part 9 Company. This evolution in governance reflects LFG's goal to become more democratic and inclusive, so that participating agencies, institutions, and disadvantaged community members can contribute to decision making. However, being located on private land has generated barriers to fully achieving this. External municipal and provincial land development pressures have also impacted LFG. Using PAA enabled us to identify and understand the different dimensions of LFG's dynamic governance and their interconnections, which provided insight into the complexity of factors, both internal and external, that impact this LFI's ability to contribute to food justice. Our analysis of LFG also examined the alignment of this initiative with FLEdGE's good food principles of food access, ecological resilience, and farmer livelihoods.

\section{Literature review}

Food systems are dynamic socio-ecological systems that are, by definition, designed to meet human needs (Eakin et al., 2017). 
While the dominant globalized and industrialized food system has prevailed due to its various strengths and far-reaching influence (Hendrickson \& Heffernan, 2002), there is growing recognition of a number of associated and overlapping socio-economic, environmental, and health related problems (e.g., Intergovernmental Panel on Climate Change, 2019; Qualman et al., 2018). As part of the neoliberal economy, the globalized food system has "transformed people into individual, me-first consumers, as opposed to engaged citizens working to address food security needs for all" (Beischer \& Corbett, 2016, p. 4). In response to the problems and vulnerabilities associated with this dominant model, an alternative food movement is calling for a re-localization and re-socialization of agri-food systems (Renting et al., 2003) that are "conditioned by local community norms, values, [and] culture" (Lyson et al., 1995, p. 108). The context-specific nature of these re-localized food systems has shaped the emergence of a variety of LFIs that are attempting to re-establish relationships between production and consumption, build local capacity through collaboration, and achieve broader sustainable development goals such as environmental protection, and social and economic equity (Albrecht \& Smithers, 2018; Pisano et al., 2011).

Situated within Edmonton's urban boundaries, LFG can be categorized as a community garden, which are an important part of cities' physical and cultural landscapes (Mougeot, 2006) and can play an important role in protecting land for food production in and around cities (Van der Jagt et al., 2017). Although critics of community gardens label them as reformist for failing to significantly challenge the dominant food system, others see their transformative potential through the lens of the "politics of hope and possibility" (Larder et al., 2014, p. 57). In addition to providing a space for food production and physical health, community gardens have been associated with social and related mental health benefits, including relaxation, recreation, community networking, relationship building, and generating a sense of place and belonging (Beckie \& Bogdan, 2010; Birky \& Strom, 2013), all of which contribute to social resilience (Van der Jagt et al., 2017). Community gardens can be a training ground for self-sufficiency, by teaching context specific food growing knowledge and skills (Beckie \& Bogdan, 2010; Wakefield et al., 2012), and for generating positive environmental values through learning about and actively engaging with local ecosystems (Bendt et al., 2013; Stocker \& Barnett, 1998). Some community gardens involve or donate to social service organizations serving low-income, disadvantaged, and food-insecure populations (Furness \& Gallaher, 2018). Engagement of all actors and the establishment of clear roles and guidelines have been shown to be critical to the use, effectiveness, and maintenance of a community garden (Bendt et al., 2013; Van der Jagt et al., 2017). Furthermore, Van der Jagt et al. (2017) found that having "a degree of hierarchical organization with an elected board of representatives responsible for administrative tasks, decision-making and regular meetings to discuss and plan activities" aids good governance of gardens (p. 271). These authors also identified the importance of garden managers' being openminded and having a receptive management style that is approachable and responsive. 
Although community gardens and other LFIs aim, in principle, to promote a new set of values and practices that advance participatory and equitable food systems, in practice "they do not automatically move us in the direction of greater social justice" (Allen, 2010, p. 306). Food justice is a critical concept and dimension of the local food movement that calls attention to issues of inclusiveness and equity through greater control over food production and consumption by those who have been marginalized by the mainstream agri-food system (Eakin et al., 2017; Gottlieb \& Joshi, 2010). Cadieux and Slocum (2015) identify food justice as an opportunity for transformative change in four key areas: equity, exchange, land, and labour. Conceptualizing food as a right under a food justice lens offers a framework to ensure that vulnerable groups have a "central and fundamental role in tackling food injustice, from the ground up" (Kneafsey et al., 2017, p. 621). Allen (2010) links food equity not only to access to resources but also to decision making processes (p. 295). Equitable and democratic food governance requires the inclusion of a broad range of actors, dialogue, social learning, collective action, and collaboration (e.g., Hospes \& Brons, 2016; Sonnino, 2019), and needs to be understood within the broader socio-political context (Kirwan et al., 2017). Identifying and analyzing food governance models that promote food justice values has become a growing area of research among food scholars.

Governance has various definitions depending on the context, but in general includes the ways initiatives are organized and operate, the norms, rules, instruments, and institutions used in decision making, and the interactions of diverse actors to make decisions to achieve certain goals (Arts et al., 2006; Hospes \& Brons, 2016). 'Good governance' is characterized by transparency, accountability, and inclusiveness (Lawrence et al., 2013). While a variety of governance models exist to promote these qualities, some are more effective than others. Various analytical frameworks have been developed to describe and understand governance structures and processes. Andrée et al. (2019), writing about food system governance and civil society organizations, place the main categories of governance arrangements - multistakeholder, cogovernance, self-governance - along a continuum of engagement and examine specific cases with respect to power, reflecting on the ways power is enacted, "from influencing, to sharing, claiming, and exerting power within their own contexts and within broader social, economic and ecological systems" (p. 19). In this book, one of the chapters focuses on the case study of YYC Growers and Distributors Cooperative in Calgary, Alberta. This case study illustrates how a group of urban and rural growers created a discursive space in order to educate the public and government about the value of local food, provide increased access, support food justice initiatives, and influence policy changes (Beckie \& Bacon, 2019). To do so, the growers leveraged both discursive and structural power (p. 94). Power, as Andrée et al. contend, is inextricably linked to governance and is part of its dynamic process of change and evolution.

In analyzing the governance arrangements of communal gardens in Europe and their ability to foster social resilience, Van der Jagt et al. (2017) adapted the Policy Arrangement Approach (PAA) (Arts et al., 2006; van Tatenhove et al., 2000). 
PAA has its roots in the field of environmental policy and was designed for understanding stability and change in decision making processes (Arts et al., 2006); the use of PAA in analyzing agriculture and food governance has been limited to date (see also Contesse et al., 2018; Liefferink, 2006). Van der Jagt et al. (2017) utilized this approach to understand governance of communal gardens through the four dimensions distinguished in PAA - actors, rules, resources, discourse - as well as the additional dimension of partnerships and participation (Lawrence et al., 2013). In PAA, actors refers to both individuals and organizations directly involved with or influencing governance, their roles, motivations, and relationships among them. Discourse refers to the norms and values of the individuals and organizations involved, as well as definition of problems, objectives, approaches to solutions, and success in achieving these. Rules provide the structure under which social cooperation takes place, and encompass both formal and informal rules. Resources refer to knowledge, skills, and material elements. It should be noted that all dimensions distinguished by PAA are identified as overlapping and interrelated; changes to one dimension will impact other dimensions.

Changes to governance arrangements can come about through reflexive processes, which create opportunities for actors to reflect on assumptions, structures, and processes, "scrutinize" current patterns, learn together, and make collective decisions for positive change (Hendriks \& Grin 2007, p. 333). Hence, reflexivity can promote experimentation, relational learning, and the development of tailor-made governance solutions (Duncan, 2015; Sonnino, 2019). Reflexivity has been an important process resulting in changes to LFG's governance, as the initiative works towards greater inclusiveness in its governance structures and processes as part of its mandate for food justice.

\section{Methods}

In this qualitative case study (Yin, 2017), we gathered data from in-depth semi-structured interviews $(\mathrm{n}=18)$, site visits to the garden and observations during LFG governance meetings, as well as documentary research. Interviews were conducted using purposeful sampling with agency representatives and community members, volunteers, post-secondary representatives, interns, LFG directors, and landowners. Site visits to the garden and observations during fall and spring semi-annual governance meetings with participating organizations occurred from 2016 to 2019. These activities helped us to gain an understanding of the way in which the garden functioned on a daily basis, as well as the roles of and relationships among different actors. Documentary research included a literature review of scholarship on LFIs, community gardens, food justice and governance, as well as an examination of LFG's website (values, mission, participating agencies), and online and printed documents and resources (rules, scheduling, reports) prepared by LFG and university researchers. 
Our analysis integrated a food justice lens with the PAA adapted by Van der Jagt et al. (2017) to identify and examine the different dimensions of LFG's dynamic governance including actors, partnerships and participation, resources, discourse, and rules. In our analysis, we grouped actors, partnerships and participation together, as certain actors (social service agencies, academic institutions) are involved with LFG through formal partnerships.

\section{Findings}

\section{Actors, partnerships and participation}

There is a wide range of actors and organizations participating in LFG, including the directors (Kelly and Doug), summer interns, social service agencies and their community members, the Edmonton Food Bank, and post-secondary institutions. Each actor and organization brings a different set of relationships, skills, knowledge, needs, and resources to the garden. Understanding the social relations between actors provides insight into how decisions are made and implemented and what factors facilitate or hinder these processes. Figure 1 identifies the different types of actors involved with LFG and the relationships among them.

Figure 1: Lady Flower Gardens Actors and Relationships

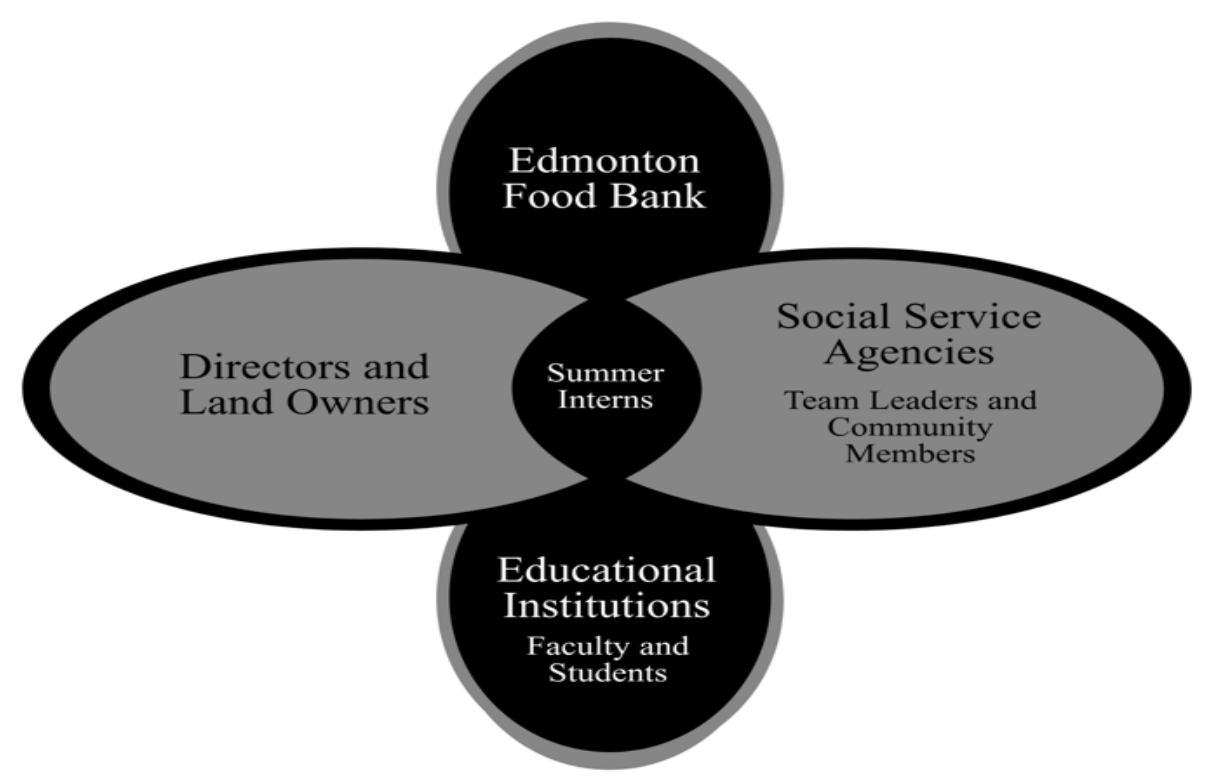




\section{Directors}

In addition to jointly initiating and overseeing the development of LFG, each co-director has additional roles, which some interviewees described as "complementary" and critical to the success of LFG. Doug, as a retired market gardener, has extensive farming experience and instructs and assists the gardeners with planting, weeding, and harvesting. Kelly has no previous gardening experience, but has worked with people with mental health and addiction issues; these experiences led her to envision a place where vulnerable and marginalized individuals could participate in collective food growing and the natural environment. In LFG, Kelly focuses on building connections, communicating, and coordinating with participating agencies and institutions, and the summer interns. Kelly has also been the key driver of changes to the governance structure of LFG.

\section{Social service agencies and community members}

Fourteen social service agencies ${ }^{1}$, providing a variety of resources and services to disadvantaged populations in Edmonton, participated in LFG in 2019, but this number varies somewhat from year to year. These agencies are responsible for insuring and transporting their community members and staff to the garden. Partnerships are formalized between LFG and individual social service agencies through yearly land-use agreements (see Rules). Between 150 and 200 community members affiliated with the different agencies participate in LFG on a weekly basis. They come to the garden for a variety of reasons, including the opportunity to enjoy fresh air, meet new people, receive fresh vegetables, and learn new gardening skills. One community member stated:

I feel like [I am] eating more veggies and doing more exercise and breathing better air... slowly you feel more energy and healthier, and then you know in that time you go there and get some vegetables and then ... you don't have to go shopping that much. So, it's all [a] benefit... Healthier mentally and physically.

Social service agency staff members added: "the most common experience I've heard is... once you leave the city you feel the sort of wash of relief over you," and coming regularly gives community members "a place where people feel a sense of belonging or a sense of value or contribution... It's a [place for] positive social interaction.”

\footnotetext{
1 The Mustard Seed; Bissell Centre; Boyle Street Community Services; Stan Daniel's Indigenous Healing Centre, Corrections Canada; Alberta Health Services Mental Health and Addictions Youth and Adults; Recovery Acres; John Howard Society; Multicultural Health Brokers Cooperative; EXCEL Society; Emmanuel Home; Ambrose Place; Capital Care; Winnifred Steward Society; Edmonton Food Bank
} 
Being involved in LFG and contributing to others in need has also had broader impacts on participants, as observed by an agency staff member: "I do think that it may have motivated some of them to get more involved in their communities and in volunteering, through participation, that element of giving back and donating, as opposed to being someone who receives."

\section{Summer interns}

Summer interns (one or two university students or recent graduates) are hired to assist with onthe-ground, day-to-day management of the garden, as well as organize special events (e.g., fundraise, forest and medicinal plant tours) and develop resources. One summer intern who participated in LFG for two years described her motivation for taking part in LFG:

It is working with people, especially people from marginalized or disadvantaged communities, but in a way that's not just charity... what drew me back is the relationships that I've built with people and seeing the difference that it makes. I think the vision of it is really cool and moving forward [includes] more education and more empowerment.

Summer interns and the directors work closely to align the daily activities with the overall direction and goals of LFG, discuss what works well, what challenges arise, and how to address these. The interns also communicate information and concerns from the directors to the member agencies and vice versa. The interns have up to date information about garden activities (i.e. where to weed and what to harvest) that they share with partner agencies, whereas agency staff have experience working with their community members and are trained in counselling, deescalation, first aid, and other necessary skills that are crucial to working with their community members.

\section{Post-secondary institutions}

LFG has also partnered with The King's University and the University of Alberta (faculties of: Extension, Arts, Agriculture, Land and Environmental Sciences (ALES), Medicine and Dentistry). Students and academics are involved in research, evaluation, and knowledge mobilization for LFG, as well as in gardening activities. For example, undergraduate students from The King's University developed communication materials for LFG as part of a class project, and students from the Faculty of Medicine and Dentistry are developing information about traditional medicines found in the old growth forest. 
These connections with post-secondary institutions are also key to future plans for expanding educational opportunities at LFG to a wider range of participants, using food as a platform for transformative learning.

\section{External agencies}

Municipal and provincial governments do not play a role in the governance of LFG but have exerted significant influence as a result of development plans for the area. LFG is located in Edmonton's Urban Growth Area, which has been designated for future residential and commercial growth (Beckie et al, 2013). There are also plans for a major provincial highway to be built in the area, which was initially slated to run through the middle of LFG; however, significant lobbying by community members and supportive organizations, such as the Greater Edmonton Alliance (GEA) ${ }^{2}$, resulted in revised plans to divert the highway elsewhere. To protect the garden and forest from future development, LFG directors went through a long and costly process of securing conservation easements on the property (New Jubilee, Evelyn's Acres), registered through the Edmonton Area Land Trust (EALT) ${ }^{3}$ (Delitala, 2019).

\section{Resources}

Resources essential to the development and ongoing success of LFG include the land and equipment, gardening expertise, private donations and grant funding, as well as skills in community organizing and networking. LFG consists of 15 acres of cultivated land, a yurt for community gatherings and events, and 75 acres of old growth forest along the North Saskatchewan River. In addition to LFG's location along the river, which makes irrigation possible, it also benefits from having some of the most productive soils in Canada (Classes 1,2, 3 ) and a unique microclimate that creates a growing season similar to that of southern parts of the province (HB Lanarc Consultants, 2012). This combination of assets, along with the vegetable production expertise, machinery and equipment of the land owner and co-director of LFG and the number of volunteers, enables a high level of production. The majority of this produce is donated to the Edmonton Food Bank and the rest is given to community gardeners and their agencies.

\footnotetext{
2 The Greater Edmonton Alliance (GEA) is an alliance of faith, labor, health education and community organizations dedicated to building a base of civic leaders to effectively stand for change they want to see in their communities. (www.greateredmontonalliance.org)

3 The Edmonton and Area Land Trust works to protect natural areas and conserve biodiversity. (www.ealt.ca)
} 
The 75 acres of old growth forest, one of the largest remaining tracts within the city limits, is home to a wide range of flora and fauna and is also an important wildlife corridor. Gardeners have supervised access to the forest where they can enjoy and learn about the natural environment, including identification and use of traditional Indigenous medicinal plants, which are abundant in the forest.

Until recently, First Nations ceremonies were allowed to be conducted in the forest, but safety regulations and the need for costly insurance have curtailed these activities.

Doug's market garden expertise has been a critical resource. LFG is part of a farm that has been in Doug's family since 1958. The largest proportion of the farm continues to be operated as a market garden by Doug's daughter and family, who have helped with LFG land preparation and seeding, and provided access to farming equipment and irrigation infrastructure. Kelly's ability to build connections and partner with other organizations in developing LFG have also been essential to the success of the initiative. Her training in leadership and democratic governance was initiated during a week-long Industrial Areas Foundation workshop in Seattle. She also seeks ongoing advice and facilitation support from provincial government community development practitioners, who provide this service free of charge, and from members of GEA. LFG operates entirely on government and foundation grants, and private donations. The directors and summer students spend a significant amount of time securing funding every year. Fundraisers have included musical events and silent auctions held in the yurt during the summer. In order to increase access to funding, a decision was made to register LFG as a Part 9 Company, which is described in more detail in Discourse.

\section{Discourse}

In the Policy Arrangement Approach, discourse refers to "the views and narratives of the actors involved, in terms of norms and values, definitions of problems and approaches to solutions" (Arts et al., 2006, p. 99), as well as the organization's objectives and how or if it is accomplishing these (Van der Jagt et al., 2017). Food justice values are central to the establishment and ongoing development of LFG, and the involvement of different actors and organizations. The primary objective of LFG is to improve the well-being of disadvantaged people living in Edmonton by providing them with opportunities for experiential learning and to grow their own fresh produce, contribute food to others in need, and build community through "learning to live sustainably with the land and each other" (Lady Flower Garden, n.d.). A food bank employee commented on the LFG model: 
I quite enjoy their model because it really is about people taking responsibility for their own food. They're not waiting for somebody else to give it to them. They're not dependent on purchasing it from the food industry. They're actively engaged in the food production piece. And it's people that normally couldn't have a garden or participate, so the building of this community is really important.

A future goal is to provide more opportunities for community members to build capacity in other ways, such as decision-making. As a short-term initiative, some community members are being trained to give tours of the garden and forest to members of the public. In addition to enabling the community members to develop skills and gain confidence in communicating with the public, it is also hoped that this contributes to their sense of belonging at LFG and could lead to their involvement in decision making.

The LFG website defines their approach as a "specialized collaboration" that involves organizations and individuals that actively practice social and environmental justice and place "the vulnerable in the center of our community" (Lady Flower Garden, n.d.). This alignment was confirmed by an agency staff member: "our mission is building community, growing hope and supporting change. And through all those three mantras, Lady Flower Gardens fits perfectly." Similarly, a faculty member of The King's University stated:

[LFG is] very focused on social justice. [Including] the idea of bringing renewal to relationships, so there's lots of things that connect in terms of work with Aboriginal, First Nations groups, and also renewal and reconciliation with... the environment... it's quite an excellent connection to what we're trying to do with our student body.

Inclusivity and democratic decision making are identified by the directors as important values and goals for LFG and over the past eight years, changes in governance processes reflect a move in this direction. During the establishment and growth phase of LFG (2012 - 2015), Kelly and Doug made all decisions and there were no formal structures or processes in place for participating organizations to provide input. In 2016, partnerships with agencies were formalized through land-use agreements and a list of rules for participation was developed (see Rules). During 2016 and 2017, students from The King's University were asked by the directors to conduct interviews with member agencies' staff, identifying what was working well and what improvements could be made. This evolved into the establishment of spring and fall meetings which enabled representatives of partnering organizations to participate in examining the successes and challenges they encountered, and collectively identify goals and strategies for the upcoming season. Despite having these processes in place, there was growing recognition by the directors and partnering organizations that LFG needed to move to a more formalized governance structure that could also increase their eligibility for grants. 
To that end, in January 2018 LFG became a self-governed Part 9 Company ${ }^{4}$ registered under the government of Alberta's Companies Act. This is a classification unique to Alberta that confers non-profit status and requires that profits or dividends are not distributed to members. What distinguishes Part 9 companies from other non-profits are significant holdings, which, in the case of LFG, is the highly valued land it is situated on. This type of entity does not require an elected board; instead, a seven-member advisory committee has been established consisting of agency and institutional representatives and others with specialized expertise, with Kelly and Doug remaining as directors.

\section{Rules}

There are specific rules and structures that frame and guide LFG activities. LFG only operates during the growing season (April to September), with participating agencies attending the garden during weekdays. Each spring, individual agencies negotiate a "land-use agreement" with the directors that guide the activities and use of the land (Lady Flower Garden, n.d.). Each agreement is unique to agencies' needs; however, all agreements must fulfill at least one of LFG's objectives - experiential/hands-on learning, collaboration, community building — and contribute to LFG's main goal of "learning to live with the land and each other" (Lady Flower Gardens, n.d.). A complex weekly schedule (mornings and afternoons, five days a week) is then developed in consultation with the agencies and posted on the website. The community gardeners are under the guidance of the agencies' team leaders, who must undergo a garden orientation at the beginning of the season to ensure rules and codes of conduct are understood. This includes ensuring that community members respect each other and all staff, as well as the equipment, the garden, and the forest. Figure 2 provides an illustration of LFG's guiding rules, which are posted at the garden. Despite having these rules, some interviewees commented that LFG still operates quite informally on a day-to-day basis, encouraging participants to understand and follow the guiding rules, but giving room to the agencies and community members to take ownership of their work as valued garden participants. LFG emphasizes the importance of equal participation and collaboration in maintaining and harvesting the garden by all involved. Social service agency staff appreciate that LFG strives for this sense of equality: "it's just really great to interact with people in a way that's not so much... service provider and client... It's just gardeners... we're all doing the same thing." During each session, participants first partake in weeding, then harvesting vegetables for the Edmonton Food Bank or other emergency food providers, and finally harvesting for themselves.

\footnotetext{
4 "Part 9 companies are formed to promote art, science, religion, charity or other similar endeavours, or they may be formed solely to promote recreation for their members. Part 9 companies are regulated by the Companies Act." (Municipal Affairs, Government of Alberta, n.d) http://www.municipalaffairs.gov.ab.ca/documents/Governance\%20Options\%20Final.pdf
} 
Figure 2: Lady Flower Gardens Rules and Guidelines for Participants

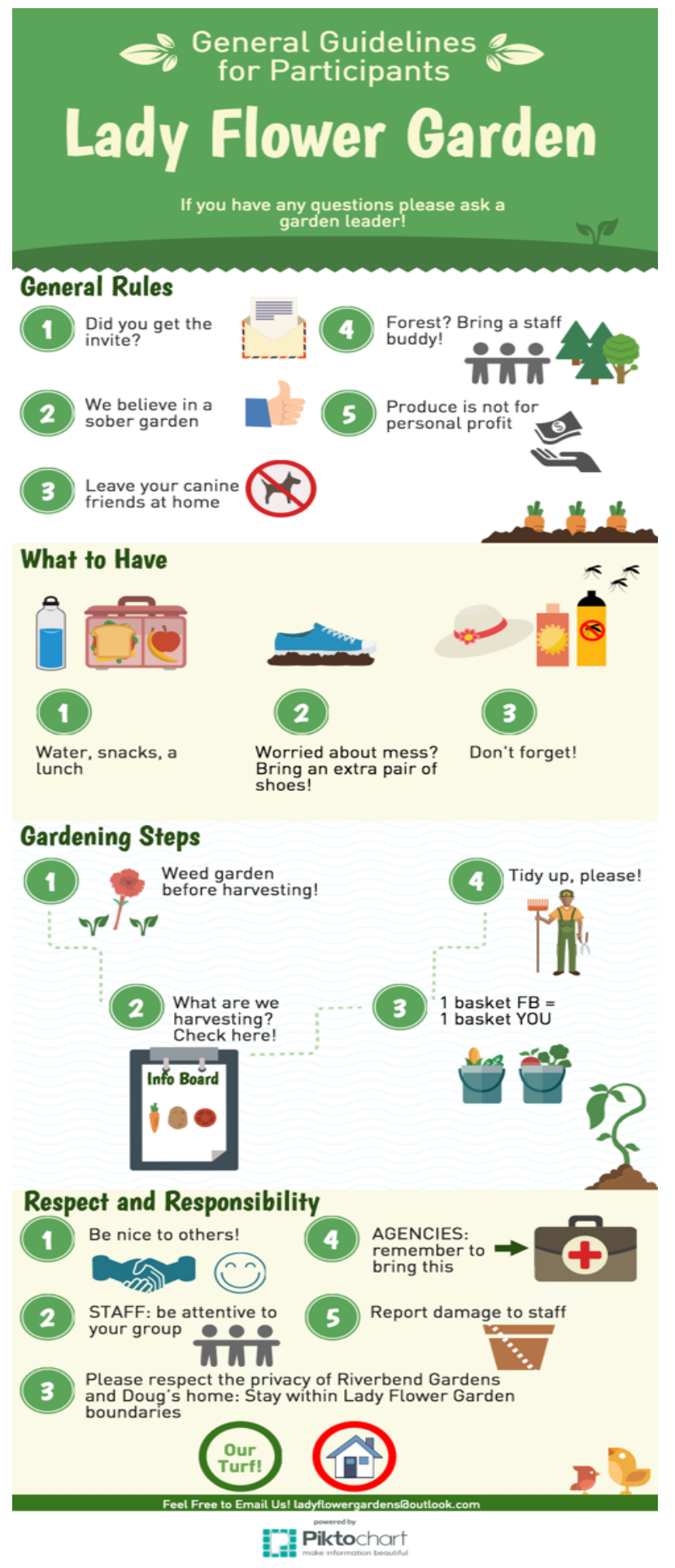




\section{Discussion}

PAA provides a structured framework for examining governance, which can be simply defined as the way in which actors work together to address problems and achieve goals (Arts et al., 2006; Hospes \& Brons, 2016). This approach distinguishes four key dimensions of governance, to which Van der Jagt et al. (2017) add partnership and participation. In our analysis of LFG, we identified discourse (why) as central and pivotal to the initiative's establishment and ongoing development. Discourse is also influential in shaping the other dimensions: actors (who) involved, their motivation for participating and the relations among them; resources (what) needed to carry out the activities; and rules (how) which provide a structure for social cooperation. Although PAA is useful as a tool for understanding and describing these dimensions, PAA also emphasizes the interconnectedness of these dimensions and how they affect stability and change. In the discussion that follows, we compare our analysis of LFG to other findings in the literature.

LFG's discourse, the "norms and values, definitions of problems and approaches to solutions" (Arts et al., 2006, p. 99), revolves around food justice for Edmonton's marginalized and disadvantaged community members. While the local food movement has been criticized for the extent of its effort to provide equitable opportunities and benefits to those experiencing social, economic, and geographic disparities (e.g., Allen, 2010), community members are core to LFG's mandate and operation. Consistent with other examples in the literature (e.g., Beckie \& Bogdan, 2010; Beischer \& Corbett, 2016; Eakin et al., 2017), the growing and harvesting of food at LFG provides opportunities to improve physical and mental well-being for disadvantaged community members through experiential learning, access to fresh produce, collaboration and sharing resources with others. In this way, LFG aligns with FLEdGE's good food principles of food access and farmer livelihoods, as diverse communities are provided with access to healthy and nutritious food, while also learning about food production and engaging in the process of food growing. 
Figure 3: Participants Gardening at Lady Flower Gardens

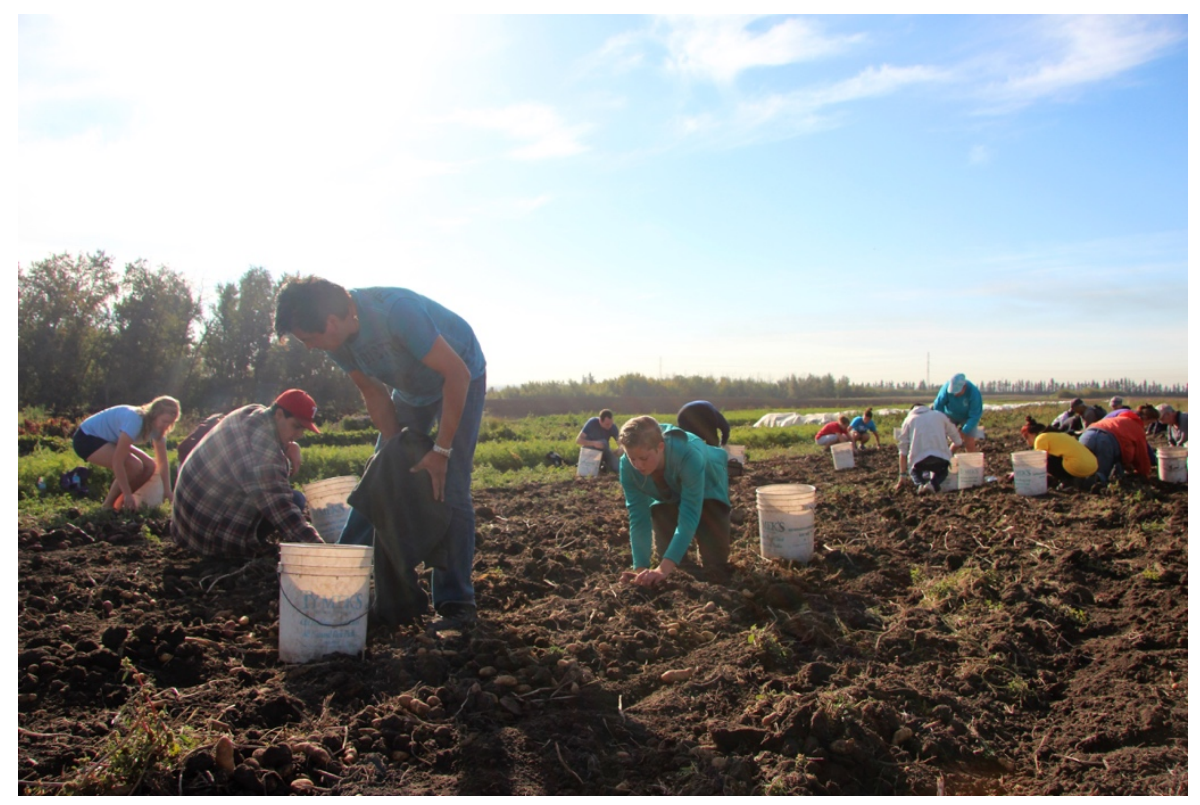

Also similar to other community gardens, a significant portion of the produce harvested at LFG is donated to a social service agency (Furness \& Gallaher, 2018). What distinguishes LFG from many other donation-model community gardens is that the gardeners harvest produce for others (Food Bank recipients) before harvesting for themselves, which creates a space for those that receive food donations to provide for others in need. Typically, those most likely to volunteer for food security initiatives are members of privileged classes (Beischer \& Corbett, 2016). By contributing to the food security of others, LFG community members gain a sense of pride and develop active citizenship, which also influences their involvement in other community activities. LFG emphasizes collaboration and solidarity among all those involved in the garden, as work is done together, side-by-side. Some interviewees commented that treating everyone as "equals" helps build trust and respect. Such collaborative community involvement and capacity building helps to forge new exchanges between diverse community members, which is crucial in promoting a food justice approach (Cadieux \& Slocum, 2015).

LFG connects community members to the land through hands-on learning in the garden and old growth forest, which is an effective way to engage participants in understanding natural processes (Bendt et al., 2013) and to promote positive values such as ecological well-being and sustainability (Cadieux \& Slocum, 2015; Stocker \& Barnett, 1998). Furthermore, by establishing conservation easements on the land, LFG is protecting prime agricultural land and a biodiverse forest; hence, this initiative also aligns strongly with the FLEdGE good food principle of ecological resilience. This, combined with improving food access, moves LFG beyond a food 
security initiative to a more transformational model of food and ecological justice (Cadieux \& Slocum, 2015).

LFG's discourse influences which organizations are involved in the initiative. LFG only partners with organizations that align with its social and environmental justice values, goals, and objectives (LFG, n.d.). Shared principles are key to strong partnerships and collaborative governance in LFIs (Lockwood et al., 2010; Van der Jagt et al., 2017). Formal agreements with social service agencies and post-secondary institutions also aid in structuring and strengthening these partnerships. Furthermore, strategically building alliances with other external organizations and institutions has enabled LFG to create greater agency and momentum for change. For example, LFG is a member organization of GEA, which organized citizens to advocate for the protection of agricultural land in northeast Edmonton (Beckie et al., 2013). LFG also has a formal and collaborative relationship with the EALT which guarantees the protection of agricultural land and the forest. Through these relationships, LFG has claimed and created spaces (Andrée et al., 2019, p. 29) for strategically and actively pursuing its values and mission, similar to the work of YYC Growers and Distributors Cooperative in Calgary (Beckie \& Bacon, 2019). Although municipal and provincial governments are not involved in the governance of LFG, they have exerted an influence on the development of the initiative. Hence, examination of the governance of LFIs also needs to take into account the broader socio-political context (Kirwan et al., 2017).

A diversity of actors is crucial to the operation of LFG, which is similar to other community gardens and is an important component of the PAA (Van der Jagt et al., 2017). LFG directors aim to increase equality and inclusivity for all actors; however power imbalances do exist, since some actors have greater decision making power over others (Gaarde, 2017). While opportunities for partnering agencies and institutions to contribute to LFG's decision making have increased through reflexive processes (Hendriks \& Grin, 2007), final decisions still rest with the directors. The transition of LFG from an informal grass-roots initiative to a government registered and self-governed Part 9 Company allows LFG to function like a non-profit organization in some ways (ie. profits or dividends are not distributed to members, expanded eligibility for funding), but it does not require an elected voting board. Instead, a board of advisors provides input on decisions, which the directors ultimately make. This power imbalance was acknowledged by the participating agencies but was not viewed negatively, as the governance arrangement is seen to be effective in meeting objectives and the values they support. LFG directors are fully aware of the power and hierarchical dynamics in the organization, and the disconnect between these and the values of food justice, which extend beyond improved access to nutritious food to inclusive and democratic decision making processes (Allen, 2010). In practicing food justice, however, LFG directors continually examine how power is distributed within the organization and try to find ways to promote equality and bring such elements into conversations with all LFG partners (Cadieux \& Slocum, 2015). For the time being, however, it remains a self-governing entity that may not fully realize a collaborative governance model until the boundaries imposed by the directors are removed. 
Actors such as Kelly and Doug are often characterized as leaders or champions who identify and address food system issues by generating "solutions that respond to the local situation and the interests and values of the communities involved" (Seyfang \& Smith, 2007, p. 585; see also Moragues-Faus \& Morgan, 2015). These actors build connections and relationships with organizations and community members, which allow for an initiative to have a broader reach and influence (Nelson et al., 2013). Kelly, in particular, can be described as having a convergent personality, someone capable of bringing people together. Paradoxically, she describes herself as a "control freak" who wants to make sure that LFG stays true to its values and objectives. Without Doug and Kelly as the champions of LFG, and their ability and determination to access resources and engage others in this initiative, LFG would not have gained the traction it has in addressing issues of food justice, social resilience, and community building.

While their time and dedication has been essential to the establishment and ongoing success of LFG, Kelly and Doug have also purposely maintained a degree of control that enables them to achieve a work-life balance they are comfortable with. As with other champions who play a crucial and demanding role in LFIs, the sustainability of the organization and work could be at risk due to their burnout and/or their desire to no longer be involved. For these reasons, Kelly and Doug are taking steps to secure a future for LFG beyond their involvement, by establishing conservation easements on the land and by developing a succession plan that may involve an educational institution taking over and expanding LFG as a land-and food-based experiential learning and living centre. The intent is to continue to prioritize the needs and involvement of disadvantaged people.

\section{Conclusion}

LFG is a local food initiative situated on private land in the northeast edge of Edmonton, Alberta, that provides opportunities for marginalized and disadvantaged individuals to develop skills in growing food and build relationships and community in a healthy and biodiverse environment. Through LFG, community members become engaged citizens by also working collectively to address food security for others through their contributions to the Edmonton Food Bank. Participants also have opportunities to access and learn about the old growth forest, which is part of LFG and an important resource for biodiversity within Edmonton. Hence, LFG plays a vital and valuable role in re-connecting vulnerable communities with food, community, and place. In this way, LFG aligns strongly with FLEdGE's good food principles of food access and ecological resilience, while also intersecting with the principle of farmer livelihoods through creating training opportunities and building capacity. 
In this qualitative case study, we integrated a food justice lens with PAA as adapted by Van der Jagt et al. (2017) to investigate LFG's evolving governance through an examination of the dimensions distinguished in this approach: actors, partnership, and participation (who), discourse (why), resources (what) and rules (how). In addition to providing a structural framework for analyzing these individual components of governance, PAA's emphasis on their interrelatedness led us to also examine how stability and change occurs. We identified food justice values and practices, LFG's 'discourse', as central to the establishment of the initiative and its ongoing development, and to shaping the other governance dimensions. LFG implements a reflexive governance approach in evaluating the alignment of current practices and policies with their values and goals, and in stimulating changes in governance structures and processes.

The establishment and vision for LFG by two individuals, its location on privately owned land, and its current structure as a Part 9 Company has thus far limited the decision making power of partnering agencies and institutions, which has prevented a transition towards true collaborative governance. All actors acknowledge this power imbalance, but this governance arrangement is seen as effective, as it meets the values and objectives that all participants support. Even though final decisions still rest with the directors, the succession plan they are in the process of creating would transition the stewardship of LFG to a public institution, which would enable the development of a more inclusive and democratic governance arrangement.

Acknowledgements: We would like to thank the reviewers and guest editor for their helpful suggestions for making improvements to this article. We would also like to acknowledge Michelle Biggs for her research assistance during the first year of this study. This research was supported by the FLEdGE research network and the Social Sciences and Humanities Research Council of Canada.

\section{References}

Abt, H., \& Ngo, S. (2018). One in six is too many: Alberta child poverty update. Edmonton Social Planning Council. https://campaign2000.ca/wpcontent/uploads/2018/11/AlbertaPovertyReportNov2018.pdf

Albrecht, C., \& Smithers, J. (2018). Reconnecting through local food initiatives? Purpose, practice and conceptions of 'value.' Agriculture and Human Values, 35(1), 67-81. https://doi.org/10.1007/s10460-017-9797-5

Allen, P. (2010). Realizing justice in local food systems. Cambridge Journal of Regions, Economy and Society, 3(2), 295-308. https://doi.org/10.1093/cjres/rsq015

Andrée, P., Clark, J. K., Levkoe, C., \& Lowitt, K. (Eds.). (2019). Civil society and social movements in food system governance. Routledge. 
Arts, B., Leroy, P., \& van Tatenhove, J. (2006). Political modernisation and policy arrangements: A framework for understanding environmental policy change. Public Organization Review, 6(2), 93-106. https://doi.org/10.1007/s11115-006-0001-4

Beckie, M., \& Bacon, E. (2019). Catalyzing change in local food system governance in Calgary, Alberta: The role of YYC growers and distributors cooperative. In P. Andrée, J. K. Clark, C. Levkoe, \& K. Lowitt (Eds.), Civil society and social movements in food system governance (pp. 81-100). Routledge.

Beckie, M. A., \& Bogdan, E. (2010). Planting roots: Urban agriculture for senior immigrants. Journal of Agriculture, Food Systems, and Community Development, 1(2), 77-89. https://doi.org/10.5304/jafscd.2010.012.004

Beckie, M. A., Hanson, L., \& Schrader, D. (2013). Farms or freeways? Citizen engagement and municipal governance in Edmonton's food and agriculture strategy development. Journal of Agriculture, Food Systems, and Community Development, 4(1), 15-31. https://doi.org/10.5304/jafscd.2013.041.004

Beischer, A. \& Corbett, J. (2016). Food justice as a response to hunger on our Canadian foodscapes: How a community-gleaning project is addressing depoliticized food insecurity through a food justice praxis. HAL Archives, halshs-01507266. https://halshs.archivesouvertes.fr/halshs-01507266/document

Bendt, P., Barthel, S., \& Colding, J. (2013). Civic greening and environmental learning inpublicaccess community gardens in Berlin. Landscape and Urban Planning, 109(1), 18-30. https://doi.org/10.1016/j.landurbplan.2012.10.003

Birky, J., \& Strom, E. (2013). Urban perennials: How diversification has created asustainable community garden movement in the United States. Urban Geography, 34(8), 1193-1216. https://doi.org/10.1080/02723638.2013.784086

Cadieux, K. V., \& Slocum, R. (2015). What does it mean to do food justice? Journal of Political Ecology, 22(1), 1-26, https://doi.org/10.2458/v22i1.21076

City of Edmonton. (2019). 2019 municipal census results. https://www.edmonton.ca/city_government/facts_figures/municipal-census-results.aspx

Clapp, J. (2014). Financialization, distance and global food politics. The Journal of Peasant Studies, 41(5), 797-814. https://doi.org/10.1080/03066150.2013.875536

Contesse, M., van Vliet, B. \& Lenhart, J. (2018). Is urban agriculture urban green space? A comparison of policy arrangements for urban green space and urban agriculture in Santiago de Chile. Land Use Policy, 71, 566-577. https://doi.org/10.1016/j.landusepol.2017.11.006

Delitala, A. (2019, May 26). Edmonton farmer seeks conservation easement to secure land's future, prevent development. Edmonton Area Land Trust. https://www.ealt.ca/ealt-in-thenews/global-visser?rq=visser

Duncan, J. (2015). “Greening” global food governance. Canadian Food Studies, 2(2), 335-344. https://doi.org/10.15353/cfs-rcea.v2i2.104 
Eakin, H., Connors, J. P., Wharton, C., Bertmann, F., Xiong, A., Stoltzfus, J. (2017). Identifying attributes of food system sustainability: Emerging themes and consensus. Agriculture and Human Values, 34(3), 757-773. https://doi.org/10.1007/s10460-016-9754-8

Edmonton Food Bank. (2018). Edmonton's food bank: Annual report 2018. https://www.edmontonsfoodbank.com/documents/66/Annual_Report_2018_Small_File_Si ze.pdf

Furness, W. W., \& Gallaher, C. M. (2018). Food access, food security and community gardens in Rockford, Il. Local Environment, 23(4), 414-430. https://doi.org/10.1080/13549839.2018.1426561

Gaarde, I. (2017). Peasants negotiating a global policy space: La vía campesina in the committee on world food security. Routledge. https://doi.org/10.4324/9781315444963

Gottlieb, R., \& Joshi, A. (2010). Food justice. MIT Press.

HB Lanarc Consultants. (2012). Agricultural inventory \& assessment: City of Edmonton city wide food and urban agriculture strategy. Edmonton, Alberta: City of Edmonton. https://landusekn.ca/sites/default/files/Ag\%20Inventory $\% 20$ and $\% 20$ Assessment $\% 20 \mathrm{Pt} \% 20$ $1 . p d f$

Hendrickson, M. K., \& Heffernan, W. D. (2002). Opening spaces through relocalization: Locating potential resistance in the weaknesses of the global food system. Sociologia Ruralis, 42(4), 347-369. https://doi.org/10.1111/1467-9523.00221

Hendriks, C. M., \& Grin, J. (2007). Contextualising reflexive governance: The politics of Dutch transitions to sustainability. Journal of Environmental Policy and Planning, 9(3-4), 333350. https://doi.org/10.1080/15239080701622790

Hospes, O., \& Brons, A. (2016). Food system governance: A systematic literature review. In A. Kennedy \& J. Liljeblad. (Eds.). Food systems governance: Challenges for justice, equality, and human rights (pp. 13-42). Routledge.

Intergovernmental Panel on Climate Change. (2019). Climate change and land: Summary for policymakers. https://www.ipcc.ch/site/assets/uploads/2019/08/4.SPM_Approved_Microsite_FINAL.pdf

Kirwan, J., Maye, D., \& Brunori, G. (2017). Acknowledging complexity in food supply chains when assessing their performance and sustainability. Journal of Rural Studies, 52, 21-32. https://doi.org/10.1016/j.jrurstud.2017.03.008

Kneafsey, M., Owen, L., Bos, E., Broughton, K., \& Lennartsson, M. (2017). Capacity building for food justice in England: The contribution of charity-led community food initiatives. Local Environment, 22(5), 621-634. https://doi.org/10.1080/13549839.2016.1245717

Lady Flower Gardens. (n.d.). Lady flower gardens. http://www.ladyflowergardens.com/

Larder, N., Lyons, K., \& Woodcock, G. (2014). Enacting food sovereignty: Values and meanings in the act of domestic food production in urban Australia. Local Environment, 19(1), 5676. https://doi.org/10.1080/13549839.2012.716409 
Lawrence, A., De Vreese, R., Johnston, M., Konijnendijk van den Bosch, C. C., \& Sanesi, G. (2013). Urban forest governance: Towards a framework for comparing approaches. Urban Forestry \& Urban Greening, 12(4), 464-473. https://doi.org/10.1016/j.ufug.2013.05.002

Liefferink, D. (2006). The dynamics of policy arrangements: Turning round the tetrahedron. In B. Arts \& P. Leroy (Eds.), Institutional dynamics in environmental governance (pp. 4568). Springer, Netherlands.

Lockwood, M., Davidson, J., Curtis, A., Stratford, E., \& Griffith, R. (2010). Governance principles for natural resource management. Society and Natural Resources, 23(10), 9861001. https://doi.org/10.1080/08941920802178214

Lyson, T. A., Gillespie, G. W., \& Hilchey, D. (1995). Farmers' markets and the local community: Bridging the formal and informal economy. American Journal of Alternative Agriculture, 10(3), 108-113. https://doi.org/10.1017/S0889189300006251

Moragues-Faus, A., \& Morgan, K. (2015). Reframing the foodscape: The emergent world of urban food policy. Environment and Planning A, 47(7), 1558-1573. https://doi.org/10.1177/0308518X15595754

Mougeot, L. J. A. (2006). Growing better cities: Urban agriculture for sustainable development. International Development Research Centre (IDRC).

Nelson, E., Knezevic, I., \& Landman, K. (2013). The uneven geographies of community food initiatives in southwestern Ontario. Local Environment, 18(5), 567-577. https://doi.org/10.1080/13549839.2013.788489

Pisano, U., Berger, G., Endl, A., \& Sedlacko, M. (2011). Sustainable developmentgovernance and policies in the light of major EU policy strategies and international developments. European Sustainable Development Network (ESDN) Quarterly Report. https://www.sdnetwork.eu/?k=quarterly\%20reports\&report_id=22

Precht, P. (2019, November 13). What is the Alberta advantage? Can it be restored? University of Calgary, School of Public Policy blog. https://www.policyschool.ca/what-is-the-albertaadvantage-can-it-be-restored/

Qualman, D., Akram-Lodhi, A. H., Desmarais, A. A., \& Srinivasan, S. (2018). Forever young? The crisis of generational renewal on Canada's farms. Canadian Food Studies, 5(3), 100 127. https://doi.org/10.15353/cfs-rcea.v5i3.284

Renting, H., Marsden, T. K., \& Banks, J. (2003). Understanding alternative food networks: Exploring the role of short food supply chains in rural development. Environment and Planning A: Economy and Space, 35(3), 393-411. https://doi.org/10.1068/a3510

Seyfang, G., \& Smith, A. (2007). Grassroots innovations for sustainable development: Towards a new research and policy agenda. Environmental Politics, 16(4), 584-603. https://doi.org/10.1080/09644010701419121

Sonnino, R. (2019). The cultural dynamics of urban food governance. City, Culture and Society, 16, 12-17. https://doi.org/10.1016/j.ccs.2017.11.001 
Statistics Canada. (2020). Labour force characteristics by census metropolitan areas. Statistics Canada. https://www150.statcan.gc.ca/t1/tbl1/en/tv.action?pid=1410029401

Stocker, L., \& Barnett, K. (1998). The significance and praxis of community-based sustainability projects: Community gardens in western Australia. Local Environment. 3(2), 179189.

Tarasuk, V. (2001). A critical examination of community-based responses to household insecurity in Canada. Health Education and Behavior, 28(4), 487499. https://doi.org/10.1177/109019810102800408

Van der Jagt, A. P. N., Szaraz, L. R., Delshammar, T., Cvejić, R., Santos, A., Goodness, J., \& Buijs, A. (2017). Cultivating nature-based solutions: The governance of communal urban gardens in the European Union. Environmental Research, 159, 264-275. https://doi.org/10.1016/j.envres.2017.08.013

Van Tatenhove, J., Arts, B., \& Leroy, P. (Eds.). (2000). Political modernisation and the environment: The renewal of environmental policy arrangements. Springer.

Wakefield, S., Fleming, J., Klassen, C. \& Skinner, A. (2012). Sweet charity, revisited: Organizational responses to food insecurity in Hamilton and Toronto, Canada. Critical Social Policy, 33(3), 427-450. https://doi.org/10.1177/0261018312458487

Yin, R. K. (2017). Case study research and applications: Design and methods (6th Ed.). SAGE Publications. 